\title{
IFIP Working Group 3.1: towards integration of computers into education
}

\author{
Tom J. van Weert \\ Former Chair of IFIP Working Group 3.1 \\ Faculty of Mathematics and Informatics \\ University of Nijmegen \\ The Netherlands
}

\begin{abstract}
Education is serving a society in transition. In the emerging society other student competencies are required. Students will only be able to develop these competencies in a changed educational setting in which information technology plays an important role. What is the current situation in secondary education with respect to information technology? What is currently possible? In which direction will developments take secondary education? How will teachers be prepared? For answering these questions there is a basis of accumulated experience in IFIP Working Group 3.1 on Secondary Education. On this basis the WCCE95 Professional Groups, sponsored by Working Group 3.1, will provide a forward look.
\end{abstract}

Main conference themes: informatics as study topic, information technology, implications, integration

Educational areas: secondary education

Study topics: computer literacy, computer science/informatics

Secondary keywords: classroom practice, curriculum development, future developments, learning models, professional development, simulation 


\section{INTRODUCTION}

The ideas presented in this paper find their basis in the work of IFIP Working Group 3.1 (WG 3.1) on Secondary Education. WG 3.1 was born at a time when main frame computers were the State of the Art. Since then it has monitored educational developments in personal computing, and predicted developments and trends. Currently computer communication and the consequences of the integration of information technology into education are focus of attention.

WG 3.1 is concerned with the development and impact of informatics, and its applications, in secondary education. Its mission is to provide a forward look from an international perspective with a special concern for the widening gap between developing and developed countries. The most recent information on research and practice is developed into a collective expertise shared by the members of the Working Group. On this basis of expertise prospective ideas about the future developments and impacts are formed and shared with others through (working) conferences, workshops and Guidelines for Good Practice. These ideas provide guidance for action, but in general there is no unique solution: specific circumstances of people and countries must be taken into account.

\section{BACKGROUND: DEVELOPMENTS IN SOCIETY}

Developments in education must be understood in the wider context of developments in society. The organization of society is changing, with information technology in a central role, and new competencies are required [1], [2].

\section{From production bureaucracy to network organization}

The organization of activities in society is changing rapidly from a hierarchical, industrial organization to a network organization. The predominant form of organization still is the industrial bureaucracy, based on the ideas of Frederick Winslow Taylor, eminently suited for mass production. These hierarchically operated bureaucracies typically have a management which has a rule for every contingency. The lines of authority and reporting are permanently fixed.

The breaking down of mass markets into markets of individual customers has lead to pressures for high quality, individual flexibility and delivery on demand. These have forced industrial bureaucracies to 're-engineer' their organization and to organize work around fundamental (business) processes. A network of teams is the result. This network is managed without much 
bureaucracy through horizontal team co-ordination and management by participation.

\section{Information technology enables organizational change}

The new organizational structures are enabled by the use of information technology. Integration of intelligent personal computers in local area, wide area and global networks empowers the individual in the distributed (business) processes and allows information to appear simultaneously in as many places as needed: information technology supports the horizontal coordination, needed in team based network organizations.

\section{Required competencies are changing}

Work in the new type of organization with its information technology orientation requires other competencies, such as: inductive thinking (first recognize a powerful solution and then seek the problems it might solve), generalist and information technology competencies (for doing the work of experts), decision-making as part of every job, handling of dynamic situations. But also competencies for team work, and higher conceptual, communication and cooperation skills to cope with the complex, distributed working environment [3]. This has consequences for secondary education.

\section{New educational content}

To allow students to develop the new competencies education will have to move its focus from low-tech to high-tech, from rote skills to academic skills, from basic intellectual abilities (reading, writing, arithmetic) to higher order intellectual skills (analyzing, abstracting, modelling), from basic vocational skills to intricate vocational skills. It should allow students to take responsibilities and make decisions. It should further social understanding, citizenship participation, ethical development and selfexpression. It should move responsibility to the students: from being taught to being responsible for your own learning [1].

Just as in the rest of society information technology will play an important role in education. Parents who as professionals have experienced empowerment by information technology, will put a direct demand on education to integrate this same technology into the learning of their children [3].

\section{Change in educational organization}

The organization of education mirrors the organizational structures in society. Educational organization as it is today is equipped to handle mass education, but is not able to cope with demands for quality and flexibility in a customer driven society. These complex hierarchies for mass education will change into student oriented learning networks, supported by integrated information technology [1]. 


\section{CURRENT SITUATION IN EDUCATION: INFORMATION TECHNOLOGY}

Education follows information technology developments in society, but at a distance [4]. These developments may be grouped into three stages. In the first stage, automation, information technology is used to automate simple, standard processes, such as business accounting. In the second stage of information, software tools support the professional at the workplace. Instead of being automated personal work processes are enhanced by integrated information technology, empowering the individual. In the third stage of communication powerful personal computers are being integrated into local area, wide area and global networks as personal, intelligent communication agents. Developments in the last two stages mentioned support the new organizational structures emerging in society.

\section{Development of IT in education}

In the first stage of development, information technology in education is aimed at automating the teaching process: teaching proper, counselling and testing. And at automating the school administration. In learning information technology appears as a subject to be learned about: learning about automation. These early developments are reflected in the 1977 IFIP WG 3.1 Working Conference "Informatics and Mathematics in secondary schools" [5] dealing with computer education for all and the notion of algorithm in Mathematics. But already then the pocket calculator was seen to empower the individual student in calculation [5, pp. 109-116], just as the computer was empowering the individual in exploration [5, pp. 77-84].

At the 1980 IFIP WG 3.1 working conference "Micro-computers in Secondary Education" the step to the next stage of information was made: information technology was seen to change teaching and learning [6, pp. 1-14]. Especially simulation was seen as a powerful instrument. Other issues in this conference were computer literacy and the development of suitable software packages [6, pp. 83-89].

The computer is used as a personal tool in teaching for preparing educational materials, administration and examinations. In learning it is potentially a personal tool for pupils in drill and practice, tutorial activities, (guided) discovery learning, building 'intellectual structures', data retrieval and manipulation, and personal support. The learning tool aspect was reflected in the discussions at the 1984 IFIP WG 3.1 working conference "Informatics and Teacher Training" [7] where the idea of 'content free' software was discussed: powerful educational tools which can be tuned to the specific needs of the individual user; a spreadsheet is a notable example. 
At the 1989 IFIP WG 3.1 working conference "Educational Software at the Secondary Level" [8] many problems associated with the design of educational software were discussed. But at this conference it also was becoming clear that the organization of education might have to adapt itself to a situation in which individual teachers and students are empowered by information technology. The ultimate situation in which the individual students "Own their own learning" was also discussed [8, pp. 91-95].

The educational use of information technology in the stage of communication is in the early phases. For example, in the 1991 IFIP WG 3.1 working conference "Impact of Informatics on the Organization of Education", Samson [1, pp. 137-148] described experiments in a special, high-tech, secondary school, the Lycée Pilote Innovant in the Parc du Futuroscope in France where networked computers were used integrated in learning. At the IFIP TC3 conference Teleteaching 93 which was held in Norway [9], innovative educational uses of computer communication were the subject of study. IFIP Working Group 3.1 has recently produced a Guideline for Good Practice on Tele-learning [10] which gives an overview over first experiences.

The potential impact of information technology is clear. The 1991 IFIP WG 3.1 working conference "Impact of Informatics on the Organization of Education" [1] concluded that: "educational organization will change with developments in society and will operate in a learning market, where individual clients will have to be 'helped to help themselves" [1, pp. 161-166]. Also a clear policy for the integration of information technology into education is needed [1, pp. 15-24]. This policy has to take account of the particular aims of the educational organization and of the local situation.

\section{WHICH DIRECTION WILL DEVELOPMENTS GO?}

Against the background of a changing society education is in need of policies of change with clear goals with respect to content, organization and infrastructure. The work in IFIP Working Group 3.1 points to a possible agenda of medium to long term goals for these policies to aim at. The keyword is: Integration.

\section{Informatics in education}

Informatics is a scientific discipline in which models, methods and techniques are developed. It will be further integrated into education [11, pp. 127-137]. A. P. Ershov in his famous keynote address at the IFIP World Conference Computers in Education in 1981 [12, pp. 1-7] already presented programming as a new literacy, allowing people to build (to program) dynamic models of reality - to build a virtual reality. New conceptual programming languages 
appear which allow easy modelling of micro-worlds of reality. A new 'Informatics for all' may develop, dealing with development and interpretation of such dynamic models.

In the Modular Informatics Curriculum for secondary school [13] which was produced by WG 3.1 under the auspices of UNESCO, such programming appears under the heading: "Modelling using Subject Oriented Programming". This is a feature of a curriculum unit, which can be offered both as general purpose programming unit and as conceptual programming unit. In the last case simulation models are built with special purpose programming tools. For example, statistical problems are modelled (solved) with a statistical package, other problems are modelled (solved) using a mathematical programmable tool such as Maple or Mathematica. But also a spreadsheet may be used.

\section{Application Oriented Informatics}

Application Oriented Informatics is the backbone of the new literacy. It includes: modelling methods and techniques, design of conceptual data structures, and program design in high level, conceptual programming languages. As "Informatics for a few" it may be offered in preparation of particular jobs or particular further studies. It may also include more advanced topics, such as software engineering and design of human-computer interfaces. The issues of (application oriented) informatics teaching are addressed in the IFIP Working Group 3.1 Guideline of Good Practice "Informatics Education in Secondary Schools" [14] .

\section{Integrative use of IT in subjects}

Students and their parents will demand and have access to the same personal working power as professionals in business and industry find on their desks [3]. Students will learn to use information technology in an integrative way and in learning will benefit from the powerful tools at their individual disposal. The integrated use of information technology will force subjects to change in content, just as this use has changed the content of work in business and industry. A clear example may be found in Mathematics where, after the changes brought about by the hand-held calculator, now the use of tools like Maple, Derive or Mathematica deeply influences the work of the professional. This will inevitably also lead to changes in the content of mathematics as a secondary school subject.

\section{Teaching organization changes into learning organization}

The educational model is changing. "The classical model of teaching, in which the Master is surrounded by his Disciples, is still alive in our classrooms, even when new technologies are used. But innovations point to the direction of 
networks of students who are allowed to participate in the building up of knowledge taking into account what the conceivers of the course know, but also what the body of all the students knows" [1, pp. 41-45].

Also bodies like the Organisation for Economic Cooperation and Development (OECD) state that to adequately prepare secondary education students for the new and changing working environments, "educational methods and pedagogy should be further developed to foster initiative, creativity, and responsibility" (New technologies in the 1990's, 1988).

Collaborative learning in multi-disciplinary teams, with integrated use of information technology, is expected to have growing importance in education, and in the end to change its organization. For developing countries there is an advantage in this learning style, because the use of scare resources may be maximised in this way.

\section{Integration of IT empowers the individual student}

Integration of intelligent personal computers in local and wide area networks empowers the individual student in the new, distributed, educational processes. This implies that some, or much learning will be outside the teachers sphere of influence. The teacher becomes a learning guide or a mentor for the students, cooperating with pupils in a learning experience. A detailed treatment of issues and impacts of the integration of information technology into education is to be found in one of the IFIP WG 3.1 Guidelines of Good Practice "Integration of Information Technology into Secondary Education: Main Issues and perspectives" [3] and in the Proceedings of the 1994 IFIP WG 3.1 Working Conference "Integrating Information Technology into Education" [11].

\section{Educational infrastructure is changing}

Traditional classrooms which perpetuate teacher-domination, will give way to open environments which promote cooperation between students, and between students and teachers. The new distributed, educational processes will have basic technological requirements, such as adequate hardware, software, and technical support. The global change in education will affect many elements of the educational infrastructure: funding, teacher training, administrative practices, curriculum development and implementation, facilities procurement and management, media, and organizational practices. School policies have to address all these interrelated infrastructural issues and aim for flexibility [1, pp. 5-13]. 


\section{WCCE95: PROFESSIONAL GROUPS PROVIDING A FORWARD LOOK}

IFIP Working Group 3.1 has sponsored several Professional Groups at WCCE95. The findings of these groups are expected to guide future work within WG 3.1 .

\section{School as a working environment}

School as a working environment will be heavily influenced by developments in society and in information technology. Integrative use of IT is expected to change subjects, to change teaching into learning and to empower the individual student. Both organization and infrastructure of schools will have to be rethought to keep schools as a good place to work and learn in.

\section{Computer supported modelling}

Modelling and simulation will rapidly evolve in secondary education. A new modelling literacy is emerging (discipline integrated informatics) and integrative use of information technology will support developments. How will this move towards modelling influence the curriculum? What is now already possible?

\section{How to make things work NOW}

A forward look on developments and impacts allows a pro-active approach of current educational problems with current technology in current education. On the basis of the available expertise things can already be made to work now.

\section{Teacher education}

In view of the expected, profound educational changes teacher education and in-service education are of prime importance. How can teachers be prepared for developments to come? The IFIP working groups on primary and secondary education (WG 3.1 and WG 3.5) will address these issues at a working conference in 1996. The agenda for this conference will be set by the findings of the WCCE95 professional group.

\section{ACKNOWLEDGEMENT}

This paper gives an overview over the work in IFIP Working Group 3.1. It quotes from a keynote paper presented at the 1993 IFIP WG 3.1/3.5 Open Conference "Informatics and changes in learning" [4, pp. 25-35] and from an invited paper presented at the 1994 IFIP Congress "Computer and Communications Evolution, the Driving Forces" [2] . 


\section{REFERENCES}

1. Samways, B. and van Weert, Tom J. (eds.) (1992) The impacts of informatics on the organization of education, Proceedings of the IFIP WG 3.1 working conference, Santa Barbara, USA, Elsevier, Amsterdam.

2. van Weert, Tom J. (1994) Education and computers: Who is in control?, in 13th World Computer Congress 94, Volume 2 (eds. K. Brunnstein and E. Raubold), Elsevier Science B.V. (North-Holland), Amsterdam, pp. 619-626.

3. Ruíz i Tarrago, F. R. (1993) Integration of Information Technology into Secondary Education: Main issues and perspectives, in Guidelines for Good Practice, IFIP Working Group 3.1 (ed. T. J. van Weert), International Federation for Information Processing, Geneva, pp. 7-15.

4. Johnson, D. C. and Samways, B. (eds.) (1993) Informatics and changes in learning, Proceedings of the IFIP WG 3.1/3.5 open conference, Gmunden, Austria, North-Holland, Amsterdam.

5. Johnson, D. C. and Tinsley, J. D. (eds.) (1977) Informatics and mathematics in secondary schools, Proceedings of the IFIP WG 3.1 working conference, Varna, Bulgaria, North-Holland, Amsterdam.

6. Tagg, E.D. (ed.) (1980) Micro-computers in secondary education, Proceedings of the IFIP WG 3.1 working conference, Paris, France, NorthHolland, Amsterdam.

7. Lovis, F. B. and Tagg, E.D. (eds.) (1984) Informatics and teacher training, Proceedings of the IFIP WG 3.1 working conference, Birmingham, GreatBritain, North-Holland, Amsterdam.

8. Tinsley, J. D. and van Weert, T. J. (eds.) (1989), Educational software at the secondary level, Proceedings of the IFIP WG 3.1 working conference, Reykjavik, Iceland, Elsevier Science Publishers B. V.

9. Davies, G. and Samways, B. (eds.) (1993) Teleteaching 93, Proceedings of the IFIP TC3 conference, Trondheim, Norway, Elsevier Science Publishers, Amsterdam. 
10. Tinsley, J. D. (1994) Tele-learning in secondary education, in Guidelines for Good Practice (ed. T. J. van Weert), IFIP Working Group 3.1, International Federation for Information Processing, Geneva.

11. Tinsley, J. D. and Watson, D. (eds.) (1995) Integrating Information Technology into Education, Proceedings of the IFIP WG 3.1 Working Conference, Barcelona, Spain, Chapman and Hall, London.

12. Lewis, R. and Tagg, D. (eds.) (1981) Computers in Education, Proceedings of the Third World Conference on Computers in Education, North-Holland Publ. Co., Amsterdam.

13. Tinsley, J. D. and van Weert, T. J. (eds.) (1994) A Modular Informatics Curriculum for Secondary Education, UNESCO, Paris.

14. Taylor, Harriet G., Aiken, Robert M., van Weert, Tom J. (1992) Informatics Education in Secondary Schools, in Guidelines for Good Practice (ed. T. J. van Weert), IFIP Working Group 3.1, International Federation for Information Processing, Geneva.

\section{ANNEXE}

\section{IFIP Working Group 3.1: Scope}

The themes of the work done within IFIP WG 3.1 concern all aspects of computers in secondary schools. Among the themes are:

- informatics education (or computer science education);

- informatics in other subjects;

- computing tools for teachers;

- computers as pedagogical tools in teaching and learning;

- influences of these tools on the content and method of teaching and learning;

- computing tools for management and administration of secondary schools;

- computers and teacher education;

- distance learning. 